Karapınar, Y. ve Küçükavşar, A. (2021). Türkçe Almanca iki dilli ve Türkçe tek dilli Türkçe öğretmeni adaylarının yazılı metinlerinde üstsöylem belirleyicileri. Ana Dili Eğitimi Dergisi, 9(3), 911-930.

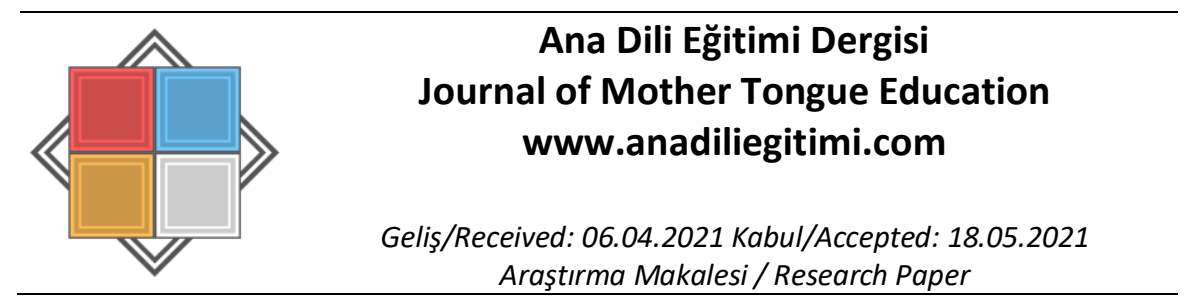

\title{
Türkçe Almanca İki Dilli ve Türkçe Tek Dilli Türkçe Öğretmeni Adaylarının Yazılı Metinlerinde Üstsöylem Belirleyicileri*
}

\author{
Yasemin KARAPINAR ${ }^{* *}$ \\ Aslıhan KÜÇÜKAVŞAR ${ }^{* * *}$
}

Öz

Bu araştırmada, Türkçe Almanca iki dilli ve Türkçe tek dilli Türkçe öğretmeni adaylarının yazılı metinlerinde kullandıkları üstsöylem belirleyicilerini belirlemek ve karşıllaştırmak amaçlanmıştır. Araştırmada, tarama ve ilişkisel araştırma deseni kullanıımıştır. Araştırmanın çalışma grubunu, Duisburg Essen Üniversitesi Türkistik bölümünde öğrenim gören 96 iki dilli Türkçe öğretmeni adayı ile Bolu Abant İzzet Baysal Üniversitesi Türkçe öğretmenliği lisans programında öğrenim gören 104 tek dilli Türkçe öğretmeni adayı oluşturmaktadır. Araştırma verilerinin elde edilmesinde, "Katıımcı Tanıma Formu" ve "Yazııı Anlatım Formu" kullanılmıştır. Üretilen metinler, Hyland'ın üstsöylem belirleyicileri sınıflandırmasına göre incelenmiştir. Grupların kullandıkları metinsel, kişilerarası ve toplam üstsöylem belirleyicileri sıklık ve dağılım verileri çözümlenmiştir. Bu bulgulara göre grupların üstsöylem belirleyicileri kullanımında istatistiksel olarak anlamlı fark tespit edilmiştir. Üstsöylem belirleyicilerini tek dilli Türkçe öğretmeni adaylarının, iki dilli Türkçe öğretmeni adaylarına göre anlamlı derecede daha fazla kullandığı belirlenmiştir. Dört grubun tamamında metinsel üstsöylem belirleyicilerinin, kişilerarası üstsöylem belirleyicilerinden daha fazla kullanıldı̆̆ı görülmüştür.

Anahtar Kelimeler: Tek dillilik, iki dillilik, metin, üstsöylem belirleyicileri

\section{Metadiscourse Markers in Writing of Turkish-German Bilingual and Turkish Monolingual Turkish Prospective Teachers}

\section{Abstract}

The aim of this study is to determine and to compare the use of metadiscourse markers in the writings of the Turkish-German bilingual and of the Turkish monolingual Turkish teacher candidates. The method of the study is a survey and correlational research design. The study has been carried out with 96 bilingual Turkish teacher candidates at the Turkic Department in Duisburg Essen University and 104 monolingual teacher candidates at the Turkish Teaching Department of Bolu Abant Izzet Baysal University. "Participant Recognition Form" and "Written Expression Form" have been used to obtain the research data. Written texts have been analyzed based on Hyland's taxonomy of metadiscourse markers. The frequency and distribution data of the textual, interpersonal, and total metadiscourse markers used by the groups have been analyzed. The findings have indicated a statistically significant difference in the use of the metadiscourse markers of the groups. The findings have also showed that the Turkish monolingual Turkish teacher candidates have used the metadiscourse markers more significantly than Turkish German bilingual candidates. Considering all four groups, it has been specified that the textual metadiscourse markers have been used more than interpersonal metadiscourse markers.

Keywords: Monolingualism, bilingualism, text, metadiscourse markers

\footnotetext{
* Bu çalışma birinci yazarın yüksek lisans tezinden üretilmiştir.

** Yüksek Lisans Öğrencisi, Bolu Abant İzzet Baysal Üniversitesi, Lisansüstü Eğitim Enstitüsü, Yabancı Dil Olarak

Türkçe Öğretimi, Bolu, karapinaryaseminn@gmail.com, ORCID: orcid.org/0000-0001-7012-1949

${ }^{* * *}$ Dr. Öğr. Üyesi, Bolu Abant İzzet Baysal Üniversitesi, Eğitim Fakültesi, Türkçe ve Sosyal Bilimler Eğitimi

Bölümü, Bolu, kucukavsar_a@ibu.edu.tr, ORCID: orcid.org/0000-0002-7827-7636
} 


\section{Giriş}

İki dillilik, bireylerin doğdukları andan itibaren iki dilin girdileri ile karşılaşarak o dilleri edinmesi ve kullanmasıdır. Bireylerin iki dilli olarak adlandırılabilmeleri için ölçütlerin neler olduğu ele alındığında çeşitli araştırmacılar tarafından farklı ölçütlerin kullanıldığı görülmektedir. Mackey (1962) iki dilliliğin, bir dil olgusu değil, dillerin karakteristik kullanımı olduğunu ve bireylerin iki dilli olarak adlandırılabilmeleri için ölçütün, iki dilde de anlama ve anlatma becerilerdeki yeterlilik olduğunu belirtmektedir. Baker (2001), birinin iki dilli olup olmadığı incelemek için dört temel dil beceri olan dinleme, konuşma okuma ve yazmadaki yetkinliklerinden yola çıkılması gerektiğini belirtmektedir. Günay (2015), bir insan gündelik yaşamında sürekli olarak iki dil kullanıyorsa bu insanı iki dilli olarak kabul etmektedir. Aksan'a (2015) göre ise iki dillilik, bireyin çeşitli nedenlerle ve değişik şartlar altında birden fazla dil edinmesi, o dili sürekli olarak kullanmasıdır.

İki dilin gelişiminin birbiriyle bağlantılı olarak ilerlediği göz önünde bulundurulduğunda, bireylerin ana dilleri, Almanca dil becerilerinin geliştirilebilmesi için en önemli araç ve faydalanılması gereken bir kaynaktır (Yağmur, 2007). Bireylerin kendilerini her iki dilde de yetkin bir biçimde ifade edebilmelerinin koşulu ana dilleri başta olmak üzere her iki dilde alınan iyi bir eğitimle temel dil becerilerinin geliştirilmesidir.

Temel dil becerileri genel olarak, anlamaya yönelik dil becerileri olan dinleme, okuma ve görsel okuma ile anlatmaya yönelik dil becerileri olan konuşma, yazma ve görsel sunu şeklinde gruplandııımaktadır. Yazma edimi, en son geliştirilen dil becerisidir. Dinleme, konuşma ve okuma edimleri yazmaya zemin hazırlamaktadır. Güneş (2016), anlatmaya yönelik dil becerilerinden biri olan yazma becerisinin, bir diğeri olan konuşma becerisine göre daha yavaş ve zor işlemlerden oluşan üretim süreçlerini içerdiğini, basit bir tümceyi yazarken zihnimizde bir dizi karmaşık işlem yapıldığını belirtmektedir.

Bireylerin, kendilerini yazılı olarak ifade ederken ise düşüncelerin anlaşılır biçimde aktarıldığı, tümce ve paragraf geçişlerinin uygun bir biçimde kurulduğu, mantıksal olarak düzgün yapılandırılmış metinler üretmeleri beklenmektedir. Birbirini izleyen sıralı ve anlamlı tümceler dizisine metin denir. Metnin, hem yazarın oluşturduğu ürün hem de okuyucunun okuma sırasında anlamlandırması bakımından süreç olma özelliklerini bir arada taşıması, o metnin tümceler toplamından farklı, kendine özgü bir bütün olduğunu göstermektedir (Günay, 2017). Metinlerin yazarın üretimiyle başlayıp okurun anlamlandırmasıyla devam eden süreç özelliğini taşıması göz önünde bulundurulduğunda, yazar bu süreçte okuyucunun metni anlamasını sağlamak, yönlendirmek amaçlarıyla çeşitli sözcük ve/veya sözcük grupları kullanmaktadır. Bunlar üstsöylem belirleyicileridir. Görevleri metinde açıkça belli olmayan bağdaşıklık ilişkilerini açığa çıkarmak ve metnin işlemlenmesini ve yorumlanmasını yönlendirmek olan sözcük ve söz öbeklerine üstsöylem belirleyicileri denir (Zeyrek, 2002). Uzun'a (2002) göre üstsöylem belirleyicileri, söyleme ilişkin söylem, toplumsal ve iletişimsel bir eylem olan yazma ediminin görünümüdür. Üstsöylem belirleyicileri, yazılı veya sözlü metinlerde, dinleyicinin veya okuyucunun, yazar tarafından verilen bilgiyi düzenlemesine, yorumlamasına ve değerlendirmesine yardımcı olmak için kullanılmaktadır (Crismore, 1993). Hyland (2005) ise üstsöylemi, metin üreticileri ile ürettikleri metinleri ve metin üreticileri ile metnin okuyucuları arasındaki etkileşimleri kavramsallaştırmaya yönelik bir yaklaşım olarak tanımlamaktadır. Tanımlarda görüldüğü üzere üstsöylem belirleyicilerinin, metnin bağdaşıklık ilişkilerini açığa çıkarma ve metnin okur tarafından düzenlenmesi, işlemlenmesi ve yorumlanması sürecini yönlendirme işlevleri bulunmaktadır. Tüm bu işlevler göz önüne alındığında, kendilerini sözlü ve yazılı olarak yetkin bir biçimde ifade etmeleri gereken Türk dilinin gelecekteki öğreticileri iki dilli ve tek dilli Türkçe öğretmeni adayları tarafından kullanılması beklenmektedir.

\section{İki Dillilik}

Bireylerin içine doğdukları toplumda çeşitli nedenlerden ötürü iki dil konuşuluyor ise bireyler, iki dil edinmekte ve iki dil aracılığıyla iletişim gerçekleştirmektedirler. Bunun sonucu olarak da iki dilli bireyler ve iki dillilik kavramı ortaya çıkmaktadır. İki dillilik tanımlarında, üzerinde durulması gereken çeşitli unsurlar bulunmaktadır. Mackey (1962) iki dilliliğin tanımlanmasında, bireylerin sahip oldukları dilleri ne kadar bildikleri, bu dilleri ne kadar ve nasıl kullandıkları, diller arası değişimin nasıl ve hangi 
koşullar altında olduğu, dillerin birbirinin kullanımını nasıl etkilediği olmak üzere dört unsurun göz önünde bulundurulması gerektiğinden söz etmektedir. Cummins (2001) iki dillilik kavramını bisiklet örneği ile şu şekilde somutlaştırmaktadır: "Tek tekerlekli bir bisiklet sizi her yere götürebilir, bir tekerleği büyük diğer küçük olan bir bisikletle de ilerleyebilirsiniz fakat bisikletin her iki tekerleği de dengeli ve tam olarak şişirilmiş ise daha uzağa gidebilir ve daha çok ilerleyebilirsiniz. Önemli olan o tekerleği yapanların ne yaptıklarını bilmesidir." U. Weinrich'e (1968, akt. Molali, 2005) göre iki dillilik, iki dilin seçenekli biçimde yaygın kullanımıdır, bunu uygulayan kişi ise iki dillidir. En basit tanımıyla, bir insan gündelik yaşamında sürekli olarak iki dil kullanıyorsa bu insan iki dillidir (Günay, 2015). Bireylerin iki dili günlük yaşamda sürekli kullanıyor oluşuyla beraber doğdukları andan itibaren iki dili de edinmeye başlamaları üzerinde durulması gereken diğer bir noktadır. Aksan’a (2015) göre iki dillilik, bireyin çeşitli nedenlerle değişik şartlar altında birden fazla dil edinmesi ve o dili sürekli olarak kullanmasıdır. Almancadaki karşılığı "Zweisprachigkeit" olan iki dilliliğin Huber (2013), iki ya da üç dili aynı oranda edinilmesi, birden çok ana diline sahip olunması durumunda gerçekleştiğini belirtmektedir. İki dilliliğin, bireyin yanında toplumda da kullanılması durumu söz konusudur. Kıran (2018), iki dilliliği bir kişinin iki dil bilmesi ya da bir toplumda iki dil kullanılması durumu olarak tanımlamaktadır. Uzun süre bir kişinin ikinci dili kendi ana dili kadar rahat konuşma yetisi olarak kabul edildiğini ekleyerek kişinin, ikinci dili üzerindeki yetkinliğinin önemine dikkat çekmektedir. Vardar (1988) da iki dilliliği, "Bir bireyin iki dil bilmesi, bir toplumda iki dil kullanması durumu" olarak tanımlayarak iki dilliliğin toplumda da görülebildiğini belirtmektedir. İki dillilikte, kullanım esnasında çeşitli nedenlerle diller arasında geçişler söz konusu olmaktadır. Tokdemir (1997) iki dilliliği, iki veya birkaç dil sisteminin paralel öğrenilmesi, gerektiğinde de bir sistemden diğerine geçiş yapılması olarak tanımlamaktadır. İki dillilik sadece birden fazla dili değil aynı zamanda birden fazla kültürü de içinde barındırmaktadır. Rolffs (2009) iki dilliliği, iki dili, iki kültürü bilmek, anlamak, bir arada kullanmak, iki dilde düşünmek ve hissetmek olarak tanımlamaktadır. Karaağaç (2011), bir kişi, bir meslek, bir topluluk veya bütün bir dil toplumunda görülen iki dil kullanma durumunun iki dillilik olduğunu belirtmektedir. Güzel (2014) ise iki dilliliğin, bireyin yabancı bir ülkede ana dilinden farklı ikinci bir dili kusursuz bilmesi, kullanması bununla beraber kendi dili ve kültürünü de yeterince bilmesi olduğunu belirtmektedir.

iki dillilikte her iki dilin doğuştan itibaren ailede kazanılmaya başlanması çok önemli bir noktadır. Çünkü ailede temeli atılan dillerin, okul yıllarında da okuryazarlıkla birlikte geliştirilmeye devam edilmesi dillerin özelliklerinin ve dillerin işlemleme süreçlerinin kavranmasının desteklenmesini sağlamaktadır. Cummins (2001), iki dilli çocukların ilkokul yıllarında da iki dildeki yeteneklerini geliştirmeye devam ettiklerinde, dilde derin anlamları ve dili daha etkili kullanma yollarını kazanacaklarını belirtmektedir. İki dilli çocukların iki dilde de daha fazla uygulama yaptıklarında, özellikle de her iki dilde de okuryazarlık geliştirdikleri yıllarda, bu iki dili karşılaştırabildiklerini ve işlemleme sürecini kazanabileceklerini belirtmektedir.

\section{Üstsöylem}

Yazar, düşüncelerini ve bakış açısını okuyucusuna aktarırken iyi anlaşılmak ister. Bu amaçla okuyucusunu da göz önünde bulundurarak metnini üretir, hatta kullandığı sözcüklerle okuyucunun anlamlandırma sürecini yönlendirebilir. Yazarın, iyi yapılandırılmış bir metinle okuyucunun anlamlandırma sürecini yönlendirmesine olanak sağlayan ögeler bulunmaktadır. Bunlar üstsöylem belirleyicileridir. Metinlerde, amaçları yalnızca tümceleri birbirine bağlamak olmayan, salt bağlaç gibi kullanılmayan, açıkça belli olmayan bağdaşıklık ilişkilerini açığa çıkaran ve metnin işlemlenmesini ve yorumlanmasını yönlendiren sözcük ve söz öbekleri üstsöylem belirleyicileridir (Zeyrek, 2002). Üstsöylem belirleyicileri, yazar ve okur arasında iletişimi sağlayan, köprü görevi gören sözcük veya sözcük öbekleridir. Üstsöylem belirleyicileri, söyleme ilişkin söylem, toplumsal ve iletişimsel bir eylem olan yazma ediminin görünümüdür (Uzun, 2002). Üstsöylem terimi, yazılı veya sözlü metinlerde, dinleyicinin veya okuyucunun, yazar tarafından verilen bilgiyi düzenlemesine, yorumlamasına ve değerlendirmesine yardımcı olmak için kullanılmaktadır (Crismore, 1993). Üstsöylem, metin üreticileri ile ürettikleri metinleri ve metin üreticileri ile metnin okuyucuları arasındaki etkileşimleri kavramsallaştırmaya yönelik bir yaklaşımdır (Hyland, 2005). Üstsöylem, yazarın söylemini ve 
söyleminin okuyucu üzerindeki olası etkilerini düzenleyen dilsel görünümlerdir (Schiffrin, 1980; Hyland, 2000).

Vande Kopple (1985) üstsöylemi söyleme ilişkin söylem veya iletişime ilişkin iletişim olarak tanımlamaktadır. Adel ise (2013) üstsöylemi, söylem hakkındaki söylem olarak tanımlamakta ve okuyucunun metni anlama süreci boyunca yönlendirilmesi için kullanıldığını belirtmektedir. Kopple (1985) yazarın üstsöylem belirleyicilerini kullanarak okuyucuya, okuma sürecinde oldukça yumuşak bir şekilde rehberlik edebileceğini ve okurun metni algılamasını, düzenlemesini sağlayabileceğini belirtmektedir. Tüm bu tanımlarda görüldüğü üzere üstsöylem belirleyicileri, yazarın ürettiği metnin okuyucusu olacağını düşünerek, okuyucunun anlama ve anlamlandırmasını kolaylaştırmak, düzenlemek ve yönlendirmek için kullandığı sözcük veya sözcük gruplarıdır.

Grabe ve Kaplan yazma sürecinde üstsöylem kullanımını etkileyen beş ana öge olduğunu belirtmektedir (Hyland, 2005):

1. Okuyucu Sayısı: Bir metnin bir kişiye, küçük bir gruba veya büyük heterojen (ayrışık) bir gruba yazılacak olması yazarın kullanacağı üstsöylem seçimlerini etkilemektedir.

2. Okuyucuların Bilinip Bilinmediği: Okuyucunun yazara yakınlık derecesi, metindeki yazarokuyucu etkileşimini ve okuyucunun metne katılımını etkilemektedir.

3. Okuyucunun Statüsü: Okuyucunun yazarla eşit, yazardan daha yüksek veya daha düşük statüde olması yazarın üstsöylem kullanımını etkilemektedir.

4. Okuyucunun Artalan Bilgisi: Okuyucunun kültürel, sosyal ve akademik artalan bilgisi yazarın üstsöylem seçimini etkilemektedir.

5. Okuyucuya Delil Gösterimi: Okuyucunun konuya ilişkin sahip olduğu bilgiler yalnızca paylaşılan ayrıntı niceliğinin değil, aynı zamanda kullanılacak delillerin niceliğini ve gösterimlerini, düşüncelerin ayrıntılandırılmasını ve desteklenmesini etkilemektedir.

Üstsöylem terimi ilk olarak 1959 yılında Zellig Haris tarafından dilin kullanımını anlamak, bir yazarın veya konuşmacının alııının metni algılamasını yönlendirmeye yönelik girişimlerini betimlemek için ortaya konulmuş ve sonrasında Williams (1981), Vande Kopple (1985) ve Crismore (1989) gibi yazarlar tarafından geliştirilmiştir (Hyland, 2005). Vande Kopple'ın 1985'te yaptığı üstsöylem sınıflandırması birçok araştırmacının üstsöylem sınıflandırmasına kaynak olmuştur. Bu araştırmacılardan biri de 1998 yılında yaptığı üstsöylem belirleyicileri sınıflandırmasıyla Hyland'dır. Hyland (2000) üstsöylemi, söylem hakkındaki söylem veya konuşma hakkındaki konuşma olarak tanımlamaktadır. Üstsöylemin yazar ile okuyucu arasındaki sosyal ve iletişimsel bir ilişkiye dayandığını, yazarın metin aracılığıyla okuyucuyu yönlendirdiğini ve okuyucu ile olan iletişimini açığa çıkardığını belirtmektedir. Hyland (2005), üstsöylem belirleyicileri aracılığıyla toplumsal ilişkileri yönetmenin yazmada önemli olduğunu vurgulayarak bir metnin ancak yazarın okuyucunun yorumlama sürecini doğru değerlendirdiğinde etkili olabileceğini belirtmektedir. Tablo 1.'de Hyland'ın üstsöylem belirleyicileri sınıflandırması yer almaktadır.

Tablo 1.

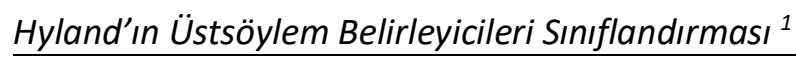

Metinsel Üstsöylem

\begin{tabular}{ll}
\hline Ulam & İşlev \\
Mantıksal Bağlayıcılar & Söylemdeki katkı, sonuç ve Fakat, ve, böylece, ama, ek \\
& karşıtlı ilişkilerini belirttir. olarak \\
& Yalnızca sözcük, tümce ve \\
& yapıları bağlamakla kalmayıp \\
& okurun söylemi daha iyi \\
& anlamasını ve yorumlamasını \\
& sağlar.
\end{tabular}

\footnotetext{
${ }^{1}$ Hyland, K. (1998). "Persuasion and Context: The Pragmatics of Academic Metadiscourse” adlı çalışmada yer alan tablodan Türkçeye çevrilmiştir.
} 
Çerçeve Belirleyiciler

İlişki Kurucular

Delil Sunucular

Açıklayıcılar
Metindeki ögelerin sırasını belirtmek ve metnin anlamının daha iyi anlaşılmasını sağlamak için söylemi özetleyen ve toparlayan ögelerdir

Metnin önceki veya sonraki bölümlerine gönderimde bulunur.

Farklı kişilerden, metinlerden yapılan alıntıları belirtir.

Yazarın ifade etmek istediği anlamı açıklayarak veya genişleterek okuyucu için daha geniş bilgi sağlayan ögelerdir. ilk olarak, sonraki, 1, 2, a, b Sonuç olarak, tekrarlayacak olursak, bu kısımda

Buradaki amacım, burada tartıştığım konu

Yukarıda belirtildiği gibi, tabloyaşekle-örneğe bakınız, bölüm 2'de belirtildiği gibi

X'e göre, (1990), X verileri

Yani, şöyle ki, örneğin, mesela, diğer bir deyişle

\section{Kişilerarası Üstsöylem}

\begin{tabular}{|c|c|c|}
\hline Ulam & İşlev & Örnek \\
\hline Olasılık Belirticiler & $\begin{array}{l}\text { Yazarın söylemlerinde tam } \\
\text { olarak emin olmadığında } \\
\text { kullandığı olasılık belirten } \\
\text { ifadelerdir. }\end{array}$ & $\begin{array}{l}\text { Belki, olabilir, mümkün, } \\
\text { mümkün olabilir, hemen hemen, } \\
\text { yaklaşık olarak, büyük ihtimalle }\end{array}$ \\
\hline Kesinlik Belirticiler & $\begin{array}{l}\text { Yazarın söylemlerinde emin } \\
\text { olduğunda kullandığı kesinlik } \\
\text { belirten ifadelerdir. }\end{array}$ & $\begin{array}{l}\text { Kesinlikle, kesin olarak, açıkça } \\
\text { görülüyor ki, şüphesiz ki }\end{array}$ \\
\hline Tutum Belirticiler & $\begin{array}{l}\text { Yazarın söylemine karşı } \\
\text { tutumunu açıkça ifade ederken } \\
\text { kullandığı ifadelerdir. }\end{array}$ & $\begin{array}{l}\mathrm{Ne} \text { yazık ki, katılıyorum, } \\
\text { katılmıyorum, } \mathrm{X} \text { iddiaları }\end{array}$ \\
\hline İlişki Belirleyiciler & $\begin{array}{l}\text { Yazarın okuyucuya başvurmak } \\
\text { ve okuyucu ile iletişim kurmak } \\
\text { için kullandığı ifadelerdir. }\end{array}$ & $\begin{array}{l}\text { Açıkçası, açıkça söylemek } \\
\text { gerekirse, unutmayın ki, } \\
\text { gördüğünüz üzere }\end{array}$ \\
\hline Kişi Belirticiler & $\begin{array}{l}\text { Yazarın kendine gönderim } \\
\text { yaptığı ifadelerdir. }\end{array}$ & $\begin{array}{l}\text { Ben, biz, benim, bizim, benimki, } \\
\text { bizimki }\end{array}$ \\
\hline
\end{tabular}

Tablo 1.'de görüldüğü üzere Hyland (1998), üstsöylem belirleyicilerini metinsel üstsöylem ve kişilerarası üstsöylem olarak ikiye ayırmıştır.

Metinsel Üstsöylem: Metinsel üstsöylem, okuyucunun yazar tarafından aktarılan bilgileri daha iyi anlaması, daha düzgün tasarlaması ve bilgileri daha inandırıcı ve tutarlı bulması için kullanılan ifadelerdir. Okuyucunun söylemi anlamlandırma ve yorumlama sürecine ilişkin olası güçlüklerine yönelik yazarın rehberlik edici ifadelerini ve metiniçi veya metinlerarası bağlantıları içermektedir. Beş işlevi bulunmaktadır:

1. Mantıksal Bağlayıcılar: Yazarın söyleminde katkı, sonuç ve karşıtlık ilişkisi belirten bağlaç ve zarflardır. Yalnızca sözcük, tümce ve yapıları bağlamakla kalmayıp okurun söylemi daha iyi anlamasını ve yorumlamasını sağlar.

2. Çerçeve Belirleyiciler: Metindeki ögelerin sırasını belirtmek ve metnin anlamının daha iyi anlaşılması için söylemi özetleyen ve toparlayan ögelerdir. Sıralamak için kullanılan "ilk olarak, sonraki, 1, 2, a, b" gibi ifadeleri, metni özetlemek ve toparlamak için kullanılan "sonuç olarak, özetle, tekrarlayacak olursak" gibi ifadeleri, söylemin hedeflerini ve 
amaçlarını duyurmak için kullanılan "buradaki amacım, burada tartıştığım konu" gibi ifadeleri ve konu değişimlerini göstermek için kullanılan "şimdi, şimdi ise" gibi ifadeleri içerir. Bu nedenle bu sınıflamadaki ifadeler söylemi çerçeveleme işlevi görür.

3. İlişki Kurucular: Metnin önceki veya sonraki kısımlarına gönderimde bulunan "Yukarıda belirtildiği gibi, tabloya-şekle-örneğe bakını, bölüm 2'de belirtildiği gibi" ifadeleri içerir. Kullanılan tabloların, şekillerin, örneklerin, ifade edilen görüşlerin okuyucu tarafından anlaşılma derecesini kuvvetlendirmek için kullanılır.

4. Delil Sunucular: Farklı kişilerden, metinlerden yapılan alıntıları belirten " $X$ 'e göre, (1990), X verileri" gibi ifadeleri içerir.

5. Açıklayıcılar: Yazarın ifade etmek istediği anlamın okuyucu tarafından çok daha fazla kazanılabilmesi için söylemi açıklayarak veya genişleterek bilgi sağlayan" Yani, şöyle ki, örneğin, mesela, diğer bir deyişle" gibi ifadeleri içerir.

Kişilerarası Üstsöylem: Yazarların kendi önerilerini, tutumlarını, bakış açılarını okuyucuya ifade etmesini sağlayan ifadelerdir. Yazarın okuyucuya yakınlığını, uzaklığını, tutumunu ifade ediş biçimini, ifade ettiği veya aktardığı görüşler hakkında düşüncelerini ve okuyucunun söylemi yapılandırma sürecinde söyleme dahil olma derecesini belirten ögelerdir.

1. Olasılık Belirticiler: Yazarın söylemlerinde tam olarak emin olmadığında kullandığı ifadelerdir. Yazarın sunduğu bilgiye uzaklığını aktarmasında önemli rol oynarlar ve ihtimal belirten "Belki, olabilir, mümkün, mümkün olabilir, hemen hemen, yaklaşık olarak" gibi ifadeleri içerirler.

2. Kesinlik Belirticiler: Yazarın söylemlerinde emin olduğunda kullandığı ifadelerdir. Yazarın sunduğu bilgiye yakınlığını aktarmasında önemli rol oynarlar ve kesinlik belirten "Kesinlikle, kesin olarak, açıkça görülüyor ki, şüphesiz ki" gibi ifadeleri içerirler.

3. Tutum Belirticiler: Tutum belirticileri yazarın bilgiye değil metnin içeriğine ilişkin tutumlarını ve yorumlarını belirtirken kullandığı "Ne yazık ki, katılıyorum, $\mathrm{X}$ iddiaları" gibi ifadeleri içerir.

4. iliş̧ki Belirleyiciler: Okurun dikkatini yoğunlaştırmak ve okuru söyleme katılımcı olarak dahil etmek için kullanılırlar. Illişki belirleyiciler aynı zamanda tutum ifadeleri de içereceğinden tutum belirticileri ile ilişki belirleyicilerini ayırt etmek zordur. Bununla beraber, tutum belirticilerin metnin içeriğine ilişkin yorumları içermesi, ilişki belirleyicilerin ise okuyucuyu söyleme dahil etmek için kullanılması birbirinden ayırt edilmesini sağlar.

5. Kişi Belirticiler: Metinde kullanılan şahıs zamirleri ve iyelik zamirleri ile yazarın metindeki varlığına açık olarak gönderimde bulunan ifadelerdir.

Üstsöylem belirleyicilerinin, metnin açıkça belli olmayan bağdaşıklık ilişkilerini açığa çıkarma, metnin okur tarafından işlemlenmesini, yorumlanmasını yönlendirme ve yazar ile okur iletişimini kolaylaştırma gibi işlevleri olduğu görülmektedir. Yazılı dilde yetkin olabilmek için de üstsöylem belirleyicilerini doğru ve yerinde kullanmanın gereği ortaya çıkmaktadır. Gerek tek dilli Türkçe öğretmeni adayları olsun gerekse iki dilli Türkçe öğretmeni adayları olsun, dili öğreten tüm öğreticilerin bu konuda çaba göstermesi gerekmektedir.

Üstsöylem belirleyicileri alanında Türkiye'de ve yurt dışında yapılan araştırmalar incelendiğinde, konuşma dilinde üstsöylem belirleyicileri kullanımı (Schiffrin, 1980; Esmer, 2009), yazılı metin üretiminde üstsöylem belirleyicileri kullanımı (Crismore, 1993; Esmer, 2018; Adel, 2018; Karakuş, 2020; Ulu, 2020), makalelerde üstsöylem belirleyicileri kullanımı (Hyland, 1996; 1998; Uzun, 2002; Zeyrek, 2002; Fidan, 2002; Dahl, 2004; Ünsal, 2008; Doyuran, 2009; Gillaerts ve Van de Velde, 2010; Çapar, 2014; Kan, 2016; Dağ Tarcan, 2019; Şen, 2019; Kirişçi, 2020), yüksek lisans ve doktora tezlerinde üstsöylem belirleyicileri kullanımı (Özbek, 1998; Köroğlu, 2017; Yuvayapan, 2018; Önel, 2020), dergilerdeki üstsöylem belirleyicileri kullanımı (Fuertes-Olivera, Velasco-Sacristan, Arribas-Bano ve Samaniego-Fernandez, 2001) ve üstsöylem belirleyicileri öğretiminin yazma yeterliliklerine etkisi (Kaya, 2019) başıkları altında sınıflandırılabilir. 


\section{Yöntem}

Türkçe Almanca iki dilli ile Türkçe tek dili Türkçe öğretmeni adaylarının yazılı metin üretimlerindeki üstsöylem belirleyicilerini Hyland'ın üstsöylem belirleyicileri sınıflandırmasına göre ortaya koymayı ve iki dillilik ile tek dilliliğin üstsöylem belirleyici kullanmını nasıl etkilediğini belirlemeyi amaçlayan bu çalışma, tarama ve ilişkisel araştırma desenindedir. Tarama çalışmaları, Karasar (2012)'ın da belirttiği gibi, geçmişte ya da halen var olan durumları, var oldukları şekliyle üzerinde herhangi bir değişiklik yapılmadan betimlenmesini amaçlar. Ayrıca büyük gruplar ile çalışma fırsatı sunar. illişkisel araştırma modeli ise, Büyüköztürk (2013)'ün tanımıyla kavramlar, olgular ve durumlar arasındaki ilişkileri, bağlantıları incelemeyi amaçlayan araştırma desenidir. Bu araştırmada Türkçe Almanca iki dilli 1. ve 4. sınıf Türkçe öğretmeni adayları ile Türkçe tek dilli 1. ve 4. sınıf Türkçe öğretmeni adayları tarafından kullanılan üstsöylem belirleyicileri arasındaki farklılıklar tarama ve ilişkisel araştırma deseni kullanılarak incelenmiştir. Araştırmanın Türkçe Almanca iki dilli ve Türkçe tek dilli Türkçe öğretmeni adaylarının yazılı metin üretimlerinde kullanacakları üstsöylem belirleyicilerini ortaya koymak, karşılaştırmak ve ulaşılacak sonuçlarla yazılı anlatım ile metindilbilim derslerinin yapılandırılmasına veri sağlamak gibi amaçları bakımından alanyazına katkı sunacağı düşünülmektedir.

\section{Çalışma Grubu}

Araştırmanın çalışma grubu, amaçlı örnekleme yoluyla seçilmiştir. Araştırmanın çalışma grubunu, Duisburg Essen Üniversitesi Türkistik Bölümünde öğrenim gören 1. sınıf 56 ve 4 . sınıf 40 Türkçe öğretmeni adayı ile Bolu Abant İzzet Baysal Üniversitesi Türkçe öğretmenliği lisans programında öğrenim gören 1. sınıf 52 ve 4. sınıf 52 öğretmeni adayı oluşturmaktadır. İki dillilik ve tek dilliliğin üstsöylem belirleyici kullanımını nasıl etkilediği belirlenmeye çalışıldığından, araştırmada Türkçe Almanca iki dilli ve Türkçe tek dilli Türkçe öğretmeni adayları seçilmiştir. Çalışma grubunun 1. ve 4. sınıf öğretmen adayları olarak seçilmesinde ise, öğretmen adaylarının öğrenim süreleri boyunca edindikleri kazanımların, deneyimlerin üstsöylem belirleyicileri kullanımına nasıl yansıdığının belirlenmeye çalışılması etkili olmuştur. Katıımcılardan veri toplamak için Etik Kurul Raporu alınmıştır.

\section{Veri Toplama Araçları}

Araştırmada veri toplama aracı olarak Türkçe Almanca iki dilli Türkçe öğretmeni adaylarına ve Türkçe tek dilli Türkçe öğretmeni adaylarına yönelik ayrı ayrı hazırlanan Katılımcı Tanıma Formu ve Yazılı Anlatım Formu kullanılmıştır. Gruplara farklı veri toplama araçları hazırlanmasının nedeni, grupların birbirinden farklı kişisel ve dilsel özellikler ile farklı artalan bilgisine sahip olmasıdır. Yazılı Anlatım Formunda öğretmen adaylarının kolaylıkla düşüncelerini aktararak metin üretebileceği konular seçilmesine özen gösterilmiştir. Konular hazırlandıktan sonra 15 uzmandan görüş alınarak düzenlemeler yapılmıştır.

\section{Verilerin Toplanması}

Katılımcı Tanıma Formu 1'de ilk olarak Türkçe Almanca iki dilli katılımcıların kişisel özelliklerine ilişkin birtakım sorular yer almıştır. Katılımcılar kişisel özelliklerine ilişkin soruları yanıtladıktan sonra 1 ayda okudukları kitap, gazete ve dergi sayılarına ilişkin soru için "Hiç, 1-5, 5-10, 10-15 ve 15 Üzeri" seçeneklerinden birini seçmiştir. Ardından katılımcılar aile içinde konuşulan dile yönelik "Çoğunlukla Türkçe, Çoğunlukla Almanca, Her ikisi de" seçenekleri bulunan soruyu yanıtlamıştır. Türkçe ve Almancayı öğrenme yaşı ve yeri sorularını yanıtlayan katılımcılar, Yazılı Anlatım Formu 1'de yer alan ve uzman görüşü alınarak hazırlanmış olan 10 adet konudan birini seçerek metin üretmiştir.

Katılımcı Tanıma Formu 2'de Türkçe tek dilli katılımcılar, ilk olarak kişisel bilgilerine iliş̧in kişisel bilgi sorularını yanıtlamışlardır. Ardından 1 ayda okudukları kitap, gazete ve dergi sayısı sorusunda "Hiç, 1-5, 5-10, 10-15 ve 15 Üzeri" seçeneklerinden birini seçerek Katılımcı Tanıma Formu 2'yi tamamlamışlardır. Sonrasında katılımcılar, Yazılı Anlatım Formu 2'yer alan ve uzman görüşü alınarak hazırlanmış olan 10 adet konudan birini seçerek metin üretmiştir.

Tüm katılımcılara Katııımcı Tanıma Formunu yanıtlamaları ve Yazılı Anlatım Formundan konu seçerek metin üretmeleri için verilen toplam süre 60 dakikadır. Katılımcıların metin üretme sürecinde sınıf 
ortamında olmalarına dikkat edilmiş, böylelikle eşit şartlarda veri toplama süreci sağlanarak katıımcıların kontrol dışı değişkenlerden etkilenmeleri önlenmeye çalışılmıştır.

\section{Verilerin Analizi}

Çalışmada, Türkçe Almanca iki dilli 1. sınıf ve 4. sınıf ile Türkçe tek dilli 1. sınıf ve 4. sınıf Türkçe öğretmeni adaylarının ürettiği yazııı metinler Hyland'ın üstsöylem belirleyicileri sınıflandırmasına göre iki uzman tarafından tek tek çözümlenmiştir. Verilerin çözümlenerek yüzde frekans bulgularının elde edilmesinde sıklık çözümlemesi yöntemi kullanılmıştır. Grupların çözümlenen verileri ilk olarak ayrı ayrı sonrasında birbirleri ile karşılaştırılarak değerlendirilmiştir. Aşağıda yer alan Tablo 2.'de birbiri ile eşleştirilerek karşılaştırılan öğretmen adayı grupları görülmektedir.

Tablo 2.

Öğretmen Adaylarının Karşılaştırılması

Gruplar

\begin{tabular}{ll}
\hline Türkçe Almanca İki Dilli 1. Sınıf & Türkçe Almanca İki Dilli 4. Sınıf \\
Türkçe Tek Dilli 1. Sınıf & Türkçe Tek Dilli 4. Sınıf \\
Türkçe Almanca İki Dilli 1. Sınıf & Türkçe Tek Dilli 1. Sınıf \\
Türkçe Almanca İki Dilli 4. Sınıf & Türkçe Tek Dilli 4. Sınıf
\end{tabular}

İki dilli ve tek dilli öğretmen adaylarının verileri Microsoft Excel kullanılarak sayısallaştırılmış, dağıım ve sıklık tabloları hazırlanmıştır. Yıldııı ve Şimşek (2016)'e göre nitel verilerin sayısallaştırımasında birkaç temel amaç vardır: "Sayısallaştırmanın güvenirliği arttırması, yanlılı̆̆ı azaltması ve sayıya dökülen verilerin tema veya kategoriler arasında karşılaştırmaya olanak sağlaması." Sayısallaştırılan verilerin Kruskal Wallis ve Mann Whitney $U$ testleri kullanılarak gruplar arası farklılaşmaları denetlenmiştir. Kruskal Wallis testi ikiden fazla örneklem ortalamasının, Mann Whitney $\mathrm{U}$ testi ise iki örneklemden elde edilen puanların birbirlerinden anlamlı bir şekilde farklılık gösterip göstermediğini test etmektedir (Büyüköztürk, 2015). Tüm grupların üstsöylem belirleyici kullanımı karşılaştırma bulguları, çoklu gruplar arasındaki puan farkının anlamlılığını gösteren Kruskal Wallis testi ile, ikili grupların üstsöylem belirleyici kullanımı karşılaştırma bulguları ise ikili gruplar arasındaki puan farkının anlamlılığını gösteren Mann Whitney $U$ testi ile analiz edilmiştir. Analizler sonucu ortaya çıkan değerler grupların metinsel üstsöylem belirleyicileri, kişilerarası üstsöylem belirleyicileri ve toplam üstsöylem belirleyicileri kullanım farklılaşmaları olmak üzere üç başlıkta değerlendirilmiştir.

\section{Geçerlik ve Güvenirlik}

Uzman çözümlemesi sonucu ortaya çıkan veriler, puanlayıcı güvenirliği hesaplama yöntemlerinden biri olan Cohen Kappa İstatistiği ile denetlenmiştir. Cohen Cappa İstatistiği, iki puanlayıcı arasındaki bağdaşım düzeyini göstermek için kullanılan ve ulaşılan değer sayesinde puanlayıcıların güvenirliğini ortaya koyan bir yöntemdir. Bu doğrultuda Tablo 3.'te uzman çözümlemelerinin Cohen Kappa İstatistiği sonuçları, Tablo 4.'te ise Landis ve Koch (1977; akt. Bilgen ve Doğan, 2017) tarafından önerilen uyum değer aralıkları yer almaktadır.

Tablo 3.

Cohen Kappa istatistiği Sonuçları

Değer $\begin{aligned} & \begin{array}{l}\text { Asymp. } \\ \text { Error }^{\mathrm{a}}\end{array} \\ & \text { Std.Approx. } T^{\mathrm{b}}\end{aligned}$ Approx. Sig.

\begin{tabular}{|c|c|c|c|c|c|}
\hline $\begin{array}{l}\text { Kappa } \\
\text { Ölçümü }\end{array}$ & Uyuşmasının & 952 & ,016 & 50,114 & ,000 \\
\hline Kişi Sayısı & & 200 & & & \\
\hline
\end{tabular}


Türkçe Almanca İki Dilli ve Türkçe Tek Dilli Türkçe Öğretmeni Adaylarının Yazılı Metinlerinde Üstsöylem Belirleyicileri

Tablo 3.'e bakıldığında iki uzmanın çözümlemesinin uyuşma değerinin 0,95 olduğu görülmektedir. Aşağıda yer alan Tablo 4.'teki Landis ve Koch (1977; akt. Bilgen ve Doğan, 2017) tarafından önerilen uyum değer aralıklarına bakıldığında puanlayıcılar arası uyumun çok yüksek olduğu görülmektedir.

Tablo 4.

Cohen Kappa İstatistiği Uyum Değer Aralıkları

\begin{tabular}{ll}
\hline Cohen Kappa Sonuçları & Uyum Değer Aralıkları \\
\hline$<0,00$ & Zayıf \\
$0,00-0,20$ & Önemsiz \\
$0,21-0,40$ & Düşük \\
$0,41-0,60$ & Orta \\
$0,61-0,80$ & Önemli \\
$0,81-1,00$ & Çok Yüksek \\
\hline
\end{tabular}

\section{Araştırma ve Yayın Etiği}

Bu çalışmada "Yükseköğretim Kurumları Bilimsel Araştırma ve Yayın Etiği Yönergesi" kapsamında uyulması belirtilen tüm kurallara uyulmuştur. Yönergenin ikinci bölümü olan "Bilimsel Araştırma ve Yayın Etiğine Aykırı Eylemler" başlığı altında belirtilen eylemlerden hiçbiri gerçekleştirilmemiştir.

\section{Etik Kurul Izni}

Kurul adı = Bolu Abant İzzet Baysal Üniversitesi Sosyal Bilimlerde İnsan Araştırmaları Etik Kurulu Karar tarihi $=21.01 .2020$

Belge sayı numarası $=2020 / 04$

\section{Bulgular}

Araştırmanın bulguları, tüm grupların (Türkçe Almanca iki dilli 1. ve 4. sınıf Türkçe öğretmeni adayları ile Türkçe tek dilli 1. ve 4. sınıf Türkçe öğretmeni adayları) metinsel, kişilerarası ve toplam üstsöylem belirleyicileri kullanım sıklığı ve bu sıklık verilerinin SPSS ile karşılaştırılması olarak ele alınmıştır. Bu bağlamda Grafik 1.'de tüm grupların kullandığı metinsel, kişilerarası ve toplam üstsöylem belirleyicileri sıkık bulguları yer almaktadır.

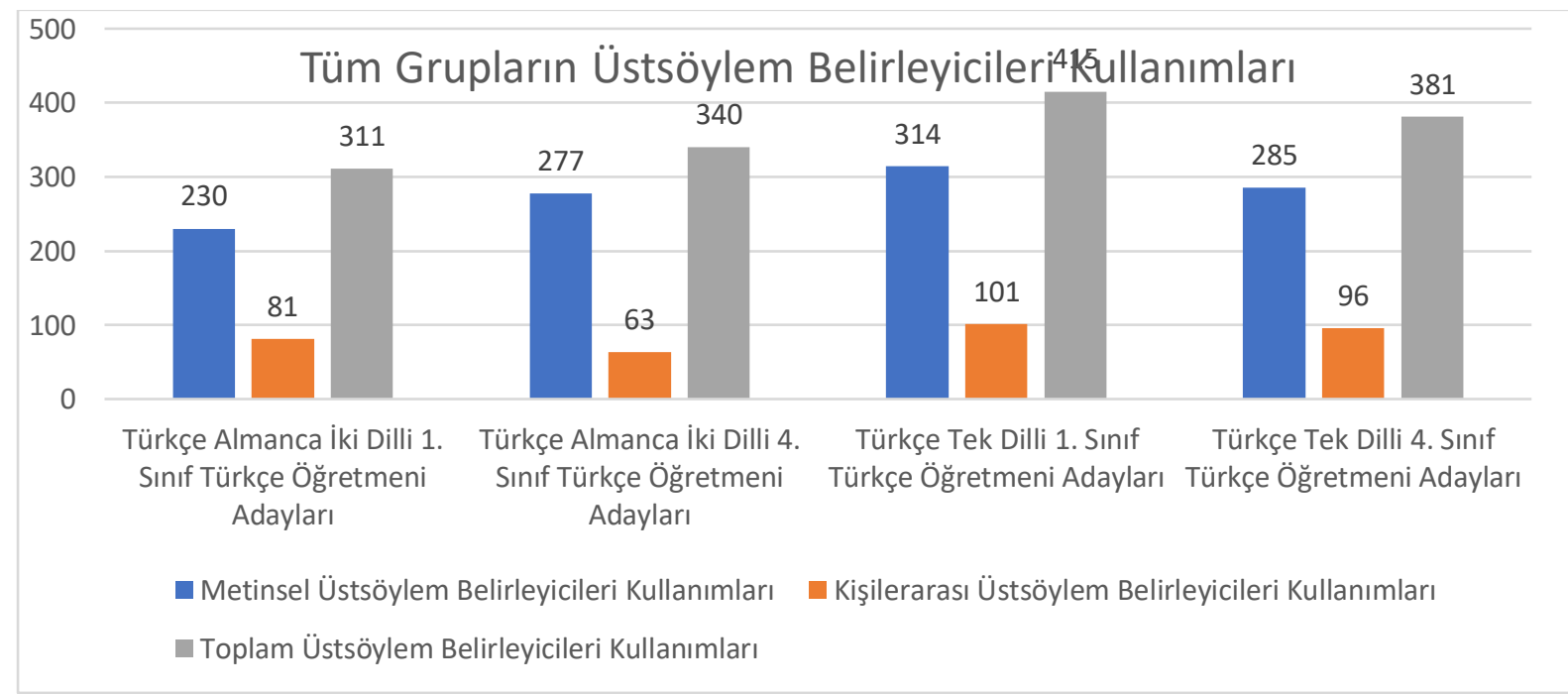

Grafik 1. Tüm Grupların Metinsel, Kişilerarası ve Toplam Üstsöylem Belirleyicileri Kullanımları 
Grafik 1.'e bakıldığında, metinsel üstsöylem belirleyicilerinin en çok Türkçe tek dilli 1. sınıf Türkçe öğretmeni adayları tarafından kullanıldığı, sonrasında sırasıyla Türkçe tek dilli 4. sınıf Türkçe öğretmeni adayları, Türkçe Almanca iki dilli 4. sınıf Türkçe öğretmeni adayları ve son sırada ise Türkçe Almanca iki dilli 1. sınıf Türkçe öğretmeni adayları tarafından kullanıldığı görülmektedir.

Kişilerarası üstsöylem belirleyicilerinin en çok Türkçe tek dilli 1. sınıf Türkçe öğretmeni adayları tarafından kullanıldığı, sonrasında sırasıyla Türkçe tek dilli 4. sınıf Türkçe öğretmeni adayları, Türkçe Almanca iki dilli 1. sınıf Türkçe öğretmeni adayları ve son sırada ise Türkçe Almanca iki dilli 4. sınıf Türkçe öğretmeni adayları tarafından kullanıldığı görülmektedir.

Bu bulgular ışığında grupların toplam üstsöylem belirleyicileri kullanımlarına bakıldığında, Türkçe tek dilli 1. sınıf Türkçe öğretmeni adayları ilk sırada yer almaktadır. Sonrasında sırasıyla Türkçe tek dilli 4. sınıf Türkçe öğretmeni adayları, Türkçe Almanca iki dilli 4. sınıf Türkçe öğretmeni adayları ve son sırada ise Türkçe Almanca iki dilli 1. sınıf Türkçe öğretmeni adayları yer almaktadır.

Tüm grupların (Türkçe Almanca iki dilli 1. ve 4. sınıf Türkçe öğretmeni adayları ile Türkçe tek dilli 1. ve 4. sınıf Türkçe öğretmeni adayları) üstsöylem belirleyici kullanımı karşılaştırmalarına bakılırken ilk olarak tüm gruplar arasında anlamlı fark olup olmadığı Kruskal Wallis ile test edilmiş, anlamlı fark söz konusu olan gruplarda Mann Whitney $U$ testi ile ikili karşılaştırmalar yapılmıştır. Bu bağlamda, aşağıda yer alan Tablo 5.'te grupların metinsel üstsöylem belirleyici kullanımları yer almaktadır.

Tablo 5.

Grupların Metinsel Üstsöylem Belirleyici Kullanımları

\begin{tabular}{|c|c|c|c|c|c|}
\hline $\begin{array}{l}\text { Metinsel Üstsöylem } \\
\text { Belirleyicileri } \\
\text { Kullanımı }\end{array}$ & $\mathrm{N}$ & Sira Ort. & $\mathrm{Sd}$ & $x^{2}$ & $P$ \\
\hline $\begin{array}{l}\text { Türkçe Almanca İki Dilli } 1 . \\
\text { Sınıf Türkçe Öğretmeni } \\
\text { Adayları }\end{array}$ & 56 & 75,32 & 3 & 16,661 & ,001* \\
\hline $\begin{array}{l}\text { Türkçe Almanca Ikki Dilli } \\
\text { 4.Sınıf Türkçe Öğretmeni } \\
\text { Adayları }\end{array}$ & 40 & 118,40 & & & \\
\hline $\begin{array}{l}\text { Türkçe Tek Dilli 1. Sınıf } \\
\text { Türkçe Öğretmeni Adayları }\end{array}$ & 52 & 111,97 & & & \\
\hline $\begin{array}{l}\text { Türkçe Tek Dilli 4. Sınıf } \\
\text { Türkçe Öğretmeni Adayları }\end{array}$ & 52 & 102,38 & & & \\
\hline
\end{tabular}

Kruskall Wallis analizi sonuçları, metinsel üstsöylem belirleyicileri kullanımının, tüm gruplarda anlamlı bir şekilde farklılaştığını göstermektedir $\left(x^{2}=16,661, p<0,05\right)$. Bu bulgu, metinsel üstsöylem belirleyicileri kullanımının 4 farklı grupta farklı sıklıkta olduğunu göstermektedir. Bu doğrultuda grupların ikili olarak karşılaştırmasında gruplar arasındaki fark ayrıntılı bir şekilde ortaya konulmuştur. Tablo 6.'da Türkçe Almanca iki dilli 1. sınıf ve Türkçe Almanca iki dilli 4. sınıf Türkçe öğretmeni adaylarının metinsel üstsöylem belirleyicileri kullanımları karşılaştırması yer almaktadır.

Tablo 6.

Türkçe Almanca iki Dilli 1. Sınıf ve Türkçe Almanca iki Dilli 4. Sınıf Türkçe Öğretmeni Adaylarının Metinsel Üstsöylem Belirleyicileri Kullanımları Karşılaştırması

\begin{tabular}{llllll}
\hline Grup & $\mathrm{N}$ & Sıra Ort. & Sıra Toplamı & $\mathrm{U}$ & $\mathrm{P}$ \\
\hline Türkçe Almanca İki & 56 & 40,24 & 2253,50 & 657,500 &, $001^{*}$ \\
Dilli 1. Sınıf Türkçe & & & & & \\
Öğretmeni Adayları & & & & & \\
\hline
\end{tabular}


Türkçe Almanca İki Dilli ve Türkçe Tek Dilli Türkçe Öğretmeni Adaylarının Yazılı Metinlerinde Üstsöylem Belirleyicileri

\begin{tabular}{|c|c|c|c|}
\hline $\begin{array}{l}\text { Türkçe Almanca İki } \\
\text { Dilli 4. Sınıf Türkçe } \\
\text { Öğretmeni Adayları }\end{array}$ & 40 & 60,06 & 2402,50 \\
\hline
\end{tabular}

Tablo 6.'ya bakıldığında Mann Whitney U analizi sonuçları, Türkçe Almanca iki dilli 1. sınıf ve Türkçe Almanca iki dilli 4. sınıf Türkçe öğretmeni adayları tarafından kullanılan metinsel üstsöylem belirleyicilerinde anlamlı bir fark olduğunu göstermektedir $(U=657,500, p<0,05)$. Sıra ortalamaları dikkate alındığında, Türkçe Almanca iki dilli 4. sınıf Türkçe öğretmeni adaylarının metinsel üstsöylem belirleyici kullanımının Türkçe Almanca iki dilli 1. sınıf Türkçe öğretmeni adaylarına göre daha yüksek olduğu görülmektedir. Tablo 7'de Türkçe tek dilli 1. sınıf ve Türkçe tek dilli 4. sınıf Türkçe öğretmeni adaylarının metinsel üstsöylem belirleyicileri kullanımlarının karşılaştırması görülmektedir.

Tablo 7.

Türkçe Tek Dilli 1. Sınıf ve Türkçe Tek Dilli 4. Sınıf Türkçe Öğretmeni Adaylarının Metinsel Üstsöylem Belirleyicileri Kullanımları Karşılaştırması

\begin{tabular}{|c|c|c|c|c|c|}
\hline Grup & $\mathrm{N}$ & Sıra Ort. & Sıra Toplamı & U & $P$ \\
\hline $\begin{array}{l}\text { Türkçe Tek Dilli } 1 . \\
\text { Sınıf Türkçe } \\
\text { Öğretmeni Adayları }\end{array}$ & 52 & 55,28 & 2874,50 & 1207,500 & ,345* \\
\hline $\begin{array}{l}\text { Türkçe Tek Dilli } 4 . \\
\text { Sınıf Türkçe } \\
\text { Öğretmeni Adayları }\end{array}$ & 52 & 49,12 & 2585,50 & & \\
\hline
\end{tabular}

Mann Whitney $U$ analizi sonuçları, Türkçe tek dilli 1. sınıf ve Türkçe tek dilli 4. sınıf Türkçe öğretmeni adayları tarafından kullanılan metinsel üstsöylem belirleyicilerinde anlamlı bir fark olmadığını göstermektedir ( $U=1207,500, p>0,05)$. Bu bağlamda, bu iki grubun metinsel üstsöylem belirleyici kullanımlarının eş değer düzeyde olduğu söylenebilir. Tablo 8'de Türkçe Almanca iki dilli 1. sınıf ve Türkçe tek dilli 1 . sınıf Türkçe öğretmeni adaylarının metinsel üstsöylem belirleyicileri kullanımları karşılaştırması yer almaktadır.

Tablo 8.

Türkçe Almanca Iki Dilli 1. Sınıf ve Türkçe Tek Dilli 1. Sınıf Türkçe Öğretmeni Adaylarının Metinsel Üstsöylem Belirleyicileri Kullanımları Karşılaştırması

\begin{tabular}{llllll}
\hline Grup & N & Sıra Ort. & Sıra Toplamı & U & P \\
\hline $\begin{array}{l}\text { Türkçe Almanca İki } \\
\text { Dilli 1. Sınıf Türkçe }\end{array}$ & 56 & 44,96 & 2517,50 & 921,500 &, $001^{*}$ \\
Öğretmeni Adayları & & & & & \\
Türkçe Tek Dilli 1. & 52 & 64,78 & 3368,50 & & \\
$\begin{array}{l}\text { Sını Türkçe } \\
\text { Öğretmeni Adayları }\end{array}$ & & & & \\
$*$ & & & &
\end{tabular}

Tablo 8.'de görüldüğü üzere, Mann Whitney $U$ analizi sonuçları, Türkçe Almanca iki dilli 1. sınıf ve Türkçe tek dilli 1. sınıf Türkçe öğretmeni adayları tarafından kullanılan metinsel üstsöylem belirleyicilerinde anlamlı bir fark olduğunu göstermektedir $(U=921,500, p<0,05)$. Sıra ortalamaları dikkate alındığında, Türkçe tek dilli 1. sınıf Türkçe öğretmeni adaylarının metinsel üstsöylem belirleyici kullanımının Türkçe Almanca iki dilli 1. sınıf Türkçe öğretmeni adaylarına göre daha yüksek olduğu 
görülmektedir. Aşağıdaki Tablo 9.'da Türkçe Almanca iki dilli 4. sınıf ve Türkçe tek dilli 4. sınıf Türkçe öğretmeni adaylarının metinsel üstsöylem belirleyicileri kullanımları karşılaştırması görülmektedir.

Tablo 9.

Türkçe Almanca Iki Dilli 4. Sınıf ve Türkçe Tek Dilli 4. Sınıf Türkçe Öğretmeni Adaylarının Metinsel Üstsöylem Belirleyicileri Kullanımları Karşılaştırması

\begin{tabular}{llllll}
\hline Grup & N & Sıra Ort. & Sıra Toplamı & U & P \\
\hline Türkçe Almanca İki Dilli & 40 & 50,78 & 2031,00 & 869,000 & 176* \\
$\begin{array}{l}\text { 4. Sınıf Türkçe } \\
\text { Öğretmeni Adayları }\end{array}$ & & & & & \\
Türkçe Tek Dilli 4. Sınıf & 52 & 43,21 & 2247,00 & & \\
Türkçe Öğretmeni & & & & & \\
Adayları & & & & & \\
\hline *p $>0,05$. & & & &
\end{tabular}

Mann Whitney $U$ analizi sonuçları, Türkçe Almanca iki dilli 4. sınıf ve Türkçe tek dilli 4. sınıf Türkçe öğretmeni adayları tarafından kullanılan metinsel üstsöylem belirleyicilerinde anlamlı bir fark olmadığını göstermektedir $(U=869,000, p>0,05)$. Bu bağlamda, bu 2 grubun metinsel üstsöylem belirleyici kullanımlarının eş değer düzeyde olduğu görülmektedir.

Tüm grupların kişilerarası üstsöylem belirleyici kullanımlarına bakılırken ilk olarak tüm gruplar arasında anlamlı fark olup olmadığı test edilmiş, anlamlı fark söz konusu olan gruplarda ikili karşılaştırmalar yapılmıştır. Bu bağlamda, Tablo 10.'da grupların kişilerarası üstsöylem belirleyici kullanımları yer almaktadır.

Tablo 10.

Grupların Kişilerarası Üstsöylem Belirleyicileri Kullanımları

\begin{tabular}{|c|c|c|c|c|c|}
\hline $\begin{array}{l}\text { Kişilerarası } \\
\text { Üstsöylem Belirleyicileri } \\
\text { Kullanımı }\end{array}$ & $N$ & Sira Ort. & Sd & $x^{2}$ & $P$ \\
\hline $\begin{array}{l}\text { Türkçe Almanca íki Dilli } 1 . \\
\text { Sınıf Türkçe Öğretmeni } \\
\text { Adayları }\end{array}$ & 56 & 91,68 & 3 & 2,848 & ,416* \\
\hline $\begin{array}{l}\text { Türkçe Almanca İki Dilli } \\
\text { 4.Sınıf Türkçe Öğretmeni } \\
\text { Adayları }\end{array}$ & 40 & 97,98 & & & \\
\hline $\begin{array}{l}\text { Türkçe Tek Dilli 1. Sınıf } \\
\text { Türkçe Öğretmeni Adayları }\end{array}$ & 52 & 109,27 & & & \\
\hline $\begin{array}{l}\text { Türkçe Tek Dilli 4. Sınıf } \\
\text { Türkçe Öğretmeni Adayları }\end{array}$ & 52 & 103,17 & & & \\
\hline
\end{tabular}

Kruskall Wallis analizi sonuçları, kişilerarası üstsöylem belirleyicileri kullanımının, gruplar arasında anlamlı bir fark olmadığını göstermektedir $\left(x^{2}=2,848, p>0,05\right)$. Bu doğrultuda grupların ikili olarak karşılaştırmasının test edilmesine gerek kalmamıştır.

Tüm grupların toplam üstsöylem belirleyici kullanımlarına bakılırken ilk olarak tüm gruplar arasında anlamlı fark olup olmadığı test edilmiş, anlamlı fark söz konusu olan gruplarda ikili karşılaştırmalar yapılmıştır. Aşağıda yer alan Tablo 11.'de grupların toplam üstsöylem belirleyici kullanımları yer almaktadır. 
Türkçe Almanca İki Dilli ve Türkçe Tek Dilli Türkçe Öğretmeni Adaylarının Yazılı Metinlerinde Üstsöylem Belirleyicileri

Tablo 11.

Grupların Toplam Üstsöylem Belirleyicileri Kullanımları

\begin{tabular}{|c|c|c|c|c|c|}
\hline $\begin{array}{l}\text { Toplam } \\
\text { Üstsöylem } \\
\text { Belirleyicileri } \\
\text { Kullanımı } \\
\end{array}$ & $\mathrm{N}$ & Sira Ort. & $\mathrm{Sd}$ & $x^{2}$ & $P$ \\
\hline $\begin{array}{l}\text { Türkçe Almanca İki } \\
\text { Dilli 1. Sınıf Türkçe } \\
\text { Öğretmeni Adayları }\end{array}$ & 56 & 75,91 & 3 & 15,262 & ,002* \\
\hline $\begin{array}{l}\text { Türkçe Almanca İki } \\
\text { Dilli 4. Sınıf Türkçe } \\
\text { Öğretmeni Adayları }\end{array}$ & 40 & 113,39 & & & \\
\hline $\begin{array}{l}\text { Türkçe Tek Dilli 1. Sınıf } \\
\text { Türkçe Öğretmeni } \\
\text { Adayları }\end{array}$ & 52 & 114,33 & & & \\
\hline $\begin{array}{l}\text { Türkçe Tek Dilli 4. Sınıf } \\
\text { Türkçe Öğretmeni } \\
\text { Adayları }\end{array}$ & 52 & 103,24 & & & \\
\hline
\end{tabular}

Tablo 11.'de görüldüğü üzere Kruskall Wallis analizi sonuçları, toplam üstsöylem belirleyicileri kullanımının, tüm gruplarda anlamlı bir şekilde farklılaştığını göstermektedir $\left(x^{2}=15,262, p<0,05\right)$. Bu bulgu, toplam üstsöylem belirleyicileri kullanımının dört farklı grupta farklı sıklıkta olduğunu göstermektedir. Bu doğrultuda, grupların ikili olarak karşılaştırmasında hangi gruplar arasındaki farkın anlamlı olduğunu daha ayrıntılı bir şekilde incelenmiştir. Aşağıdaki tabloda, Türkçe Almanca iki dilli 1. sınıf ve Türkçe Almanca iki dilli 4. sınıf Türkçe öğretmeni adaylarının metinsel üstsöylem belirleyicileri kullanımları karşılaştırması görülmektedir.

Tablo 12.

Türkçe Almanca iki Dilli 1. Sınıf ve Türkçe Almanca Iki Dilli 4. Sınıf Türkçe Öğretmeni Adaylarının Toplam Üstsöylem Belirleyicileri Kullanımları Karşılaştırması

\begin{tabular}{llllll}
\hline Grup & N & Sıra Ort. & Sıra Toplamı & U & P \\
\hline $\begin{array}{l}\text { Türkçe Almanca Iki } \\
\text { Dilli 1. Sınıf Türkçe }\end{array}$ & 56 & 41,23 & 2309,00 & 713,000 &, $002^{*}$ \\
Öğretmeni Adayları & & & & & \\
Türkçe Almanca Iki & 40 & 58,68 & 2347,00 & & \\
$\begin{array}{l}\text { Dilli 4. Sınıf Türkçe } \\
\text { Öğretmeni Adayları }\end{array}$ & & & & & \\
*p<0,05. & & & &
\end{tabular}

Tablo 12.'ye bakıldığında Mann Whitney U analizi sonuçları, Türkçe Almanca iki dilli 1. sınıf ve Türkçe Almanca iki dilli 4. sınıf Türkçe öğretmeni adayları tarafından kullanılan toplam üstsöylem belirleyicilerinde anlamlı bir fark olduğunu göstermektedir $(U=713,000, p<0,05)$. Sıra ortalamaları dikkate alındığında, Türkçe Almanca iki dilli 4. sınıf Türkçe öğretmeni adaylarının toplam üstsöylem belirleyici kullanımının Türkçe Almanca iki dilli 1. sınıf Türkçe öğretmeni adaylarına göre daha yüksek olduğu görülmektedir. Tablo 13.'te Türkçe tek dilli 1. sınıf ve Türkçe tek dilli 4. sınıf Türkçe öğretmeni adaylarının toplam üstsöylem belirleyicileri kullanımları karşılaştırması yer almaktadır. 
Tablo 13.

Türkçe Tek Dilli 1. Sınıf ve Türkçe Tek Dilli 4. Sınıf Türkçe Öğretmeni Adaylarının Toplam Üstsöylem Belirleyicileri Kullanımları Karşılaştırması

\begin{tabular}{llllll}
\hline Grup & N & Sıra Ort. & Sıra Toplamı & U & P \\
\hline $\begin{array}{l}\text { Türkçe Tek Dilli 1. } \\
\text { Sını Türkçe }\end{array}$ & 52 & 55,45 & 2883,50 & 1198,500 &, $317^{*}$ \\
$\begin{array}{l}\text { Öğretmeni Adayları } \\
\text { Türkçe Tek Dilli 4. }\end{array}$ & 52 & 49,55 & 2576,50 & & \\
$\begin{array}{l}\text { Sınıf Türkçe } \\
\text { Öğretmeni Adayları }\end{array}$ & & & & & \\
*p $>0,05$. & & & & \\
\hline
\end{tabular}

Mann Whitney U analizi sonuçları, Türkçe tek dilli 1. sınıf ve Türkçe tek dilli 4. sınıf Türkçe öğretmeni adayları tarafından kullanılan toplam üstsöylem belirleyicilerinde anlamlı bir fark olmadığını göstermektedir $(U=1198,500, p>0,05)$. Bu bağlamda, bu iki grubun metinsel üstsöylem belirleyici kullanımlarının eş değer düzeyde olduğu görülmektedir. Tablo 14.'te Türkçe Almanca iki dilli 1. sınıf ve Türkçe tek dilli 1 . sınıf Türkçe öğretmeni adaylarının toplam üstsöylem belirleyicileri kullanımları karşılaştırması görülmektedir.

Tablo 14.

Türkçe Almanca iki Dilli 1. Sınıf ve Türkçe Tek Dilli 1. Sınıf Türkçe Öğretmeni Adaylarının Toplam Üstsöylem Belirleyicileri Kullanımları Karşılaştırması

\begin{tabular}{llllll}
\hline Grup & N & Sıra Ort. & Sıra Toplamı & U & P \\
\hline Türkçe Almanca İki & 56 & 44,37 & 2484,50 & 888,500 &, $000^{*}$ \\
Dilli 1. Sınıf Türkçe & & & & & \\
Öğretmeni Adayları & & & & \\
Türkçe Tek Dilli 1. & 52 & 65,41 & 3401,50 & & \\
$\begin{array}{l}\text { Sinıf Türkçe } \\
\text { Öğretmeni Adayları }\end{array}$ & & & & & \\
* & & &
\end{tabular}

Tablo 14.'te görüldüğü üzere Mann Whitney U analizi sonuçları, Türkçe Almanca iki dilli 1. sınıf ve Türkçe tek dilli 1 . sınıf Türkçe öğretmeni adayları tarafından kullanılan toplam üstsöylem belirleyicilerinde anlamlı bir fark olduğunu göstermektedir $(U=888,500, p<0,05)$. Sıra ortalamaları dikkate alındığında, Türkçe tek dilli 1 . sınıf Türkçe öğretmeni adaylarının toplam üstsöylem belirleyici kullanımının Türkçe Almanca iki dilli 1. sınıf Türkçe öğretmeni adaylarına göre daha yüksek olduğu görülmektedir. Aşağıda yer alan Tablo 15.'te Türkçe Almanca iki dilli 4. sınıf ve Türkçe tek dilli 4. sınıf Türkçe öğretmeni adaylarının toplam üstsöylem belirleyicileri kullanımları karşılaştırması yer almaktadır.

Tablo 15.

Türkçe Almanca iki Dilli 4. Sınıf ve Türkçe Tek Dilli 4. Sınıf Türkçe Öğretmeni Adaylarının Toplam Üstsöylem Belirleyicileri Kullanımları Karşılaştırması

\begin{tabular}{llllll}
\hline Grup & N & Sıra Ort. & Sıra Toplamı & U & P \\
\hline $\begin{array}{l}\text { Türkçe Almanca İki } \\
\text { Dilli 4. Sınıf Türkçe }\end{array}$ & 40 & 49,16 & 1966,50 & 933,500 &, $400^{*}$ \\
$\begin{array}{l}\text { Öğretmeni Adayları } \\
\text { Türkçe Tek Dilli 4. }\end{array}$ & 52 & 44,45 & 2311,50 & & \\
$\begin{array}{l}\text { Sınıf Türkçe } \\
\text { Öğretmeni Adayları }\end{array}$ & & & & & \\
\hline
\end{tabular}


${ }^{*} p>0,05$.

Mann Whitney $U$ analizi sonuçları, Türkçe Almanca iki dilli 4. sınıf ve Türkçe tek dilli 4. sınıf Türkçe öğretmeni adayları tarafından kullanılan toplam üstsöylem belirleyicilerinde anlamlı bir fark olmadığını göstermektedir $(U=933,500, p>0,05)$. Bu bağlamda, bu iki grubun toplam üstsöylem belirleyici kullanımlarının eş değer düzeyde olduğu görülmektedir.

Araştırmanın diğer bir bulgusu ise öğretmen adaylarının yazılı metinlerinde kullandıkları sözcük sayısıdır. Grafik 2.'de tüm grupların (Türkçe Almanca iki dilli 1. sınıf ve 4. sınıf Türkçe öğretmeni adayları, Türkçe tek dilli 1 . sınıf ve 4. sınıf Türkçe öğretmeni adayları) katılımcı sayısı ve gruplar tarafından kullanılan sözcük sayısı yer almaktadır.

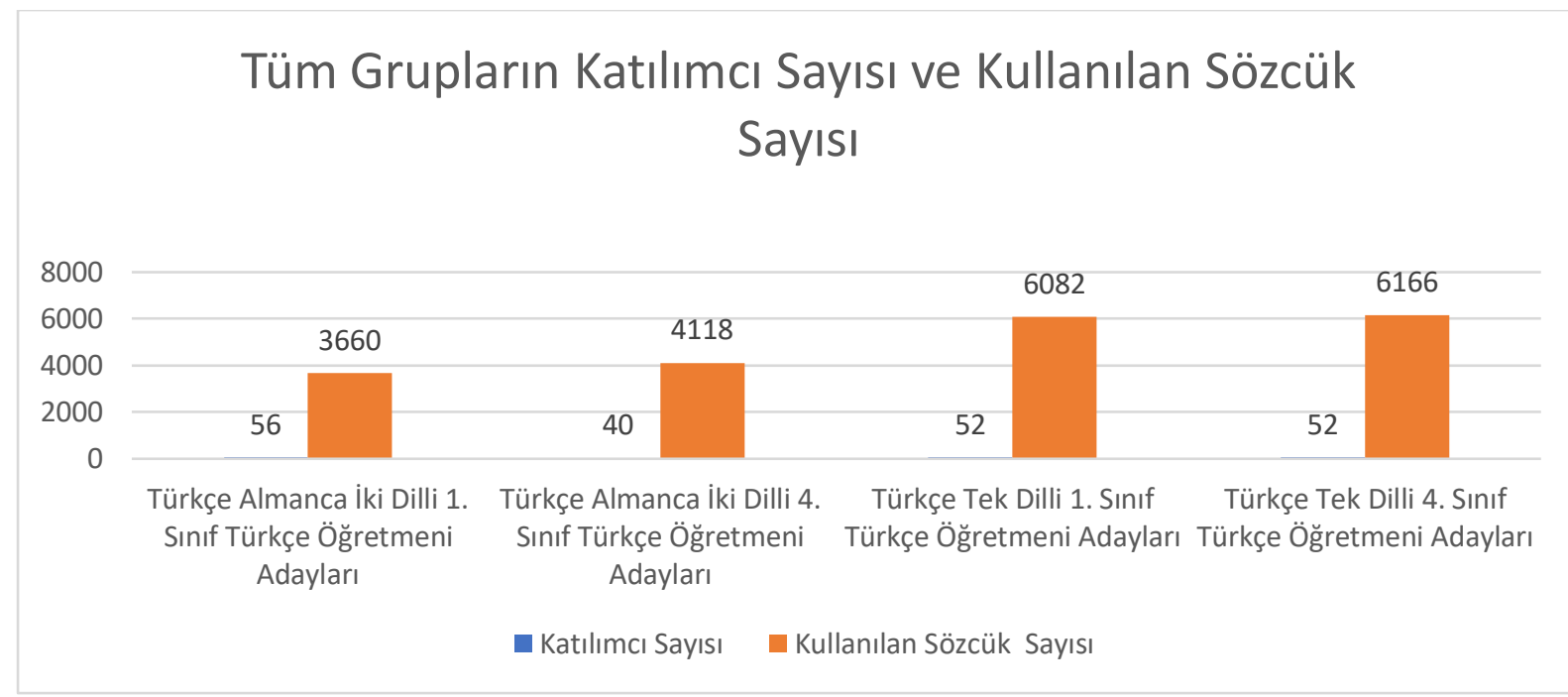

Grafik 2. Tüm Grupların Katııımcı Sayısı ve Gruplar Tarafından Kullanılan Sözcük Sayısı

Tartışma ve Sonuç

Araştırmanın bulgularına göre varılan sonuçlar aşağıdaki gibidir:

- Tüm grupların üstsöylem belirleyicileri kullanımlarına bakıldığında, üstsöylem belirleyicilerini en çok kullanan grup Türkçe tek dilli 1. sınıf Türkçe öğretmeni adaylarıdır. Sonrasında sırasıyla Türkçe tek dilli 4. sınıf, Türkçe Almanca iki dilli 4. sınıf Türkçe öğretmeni adayları gelmektedir. Son sırada ise Türkçe Almanca iki dilli 1. sınıf Türkçe öğretmeni adayları bulunmaktadır. Türkçe Almanca iki dilli ile Türkçe tek dili Türkçe öğretmeni adaylarının yazılı metin üretimlerindeki üstsöylem belirleyicilerini ortaya koymayı ve iki dillilik ile tek dilliliğin üstsöylem belirleyici kullanımını nasıl etkilediğini belirlemeyi amaçlayan bu araştırma sonucunda, Türkçe tek dilli Türkçe öğretmeni adaylarının ürettikleri yazılı metinlerde, Türkçe Almanca iki dilli Türkçe öğretmeni adaylarına göre üstsöylem belirleyicilerine daha fazla yer verdiği görülmektedir. Bunun sebebi, tek dilli öğretmen adaylarının metin üretme sürecinde metnin okuyucusunu daha fazla önemsemeleri olarak açıklanabilir. Bununla beraber Türkçe olarak üretilen yazılı metinlerde Türkçe tek dilli öğretmen adaylarının Türkçe Almanca iki dilli öğretmen adaylarına göre daha fazla sözcük ve daha fazla üstsöylem belirleyicileri kullanmış olmalarında, tek dilli öğretmen adaylarının dil edinim sürecinde ana dillerinin özelliklerini daha fazla kavramış olmalarının etkili olduğu söylenebilir. Tek dilli öğretmen adaylarının Türkçedeki artalan bilgilerinin, iki dilli öğretmen adaylarına göre daha geniş olduğu söylenebilir. Dildeki bu yetkinliğin de hem metin üretme sürecine hem de bu süreçte kullanılan sözcük sayısına yansımış olduğu görülmektedir. Grupların tamamında metinsel üstsöylem belirleyicileri kişilerarası üstsöylem belirleyicilerinden daha çok kullanılmıştır. Bu bağlamda tüm katılımcılar, yazdıkları metinlerde aktardıkları bilgilerin okuyucu tarafından daha iyi 
anlaşılması, daha inandırıcı ve tutarlı bulunması amaçlarını; kendi öneri, tutum ve bakış açılarını okuyucuya aktarma, metinde kendi varlıklarını okuyucuya hissettirme ve okuyucuyu metne dahil etme amaçlarına tercih etmişlerdir denebilir. Bu sonuç Hyland (1998), Uzun (2002), Fidan (2002), Esmer (2018) ve Dağ Tarcan'ın (2019) çalışmalarından elde ettikleri metinsel üstsöylem belirleyicileri kişilerarası üstsöylem belirleyicilerinden daha çok kullanıldığı sonucunu desteklemektedir. Bununla beraber Crismore'un (1993) lisansüstü öğrencilerle yürütmüş olduğu çalışmada ulaştığı, kişilerarası üstsöylem belirleyicilerinin metinsel üstsöylem belirleyicilerinden daha fazla kullanıldığı sonucu ile örtüşmemektedir. Bu farklılığın Crismore'un öğrencilerden ikna edici bir metin yazmalarını ve bu metni desteklemelerini istemesinden kaynaklandığı söylenebilir. Ayrıca "Okuyucularınız olacağını aklınızdan çıkarmayın" gibi yönergeler vermesinin de etkili olduğu düşünülmektedir.

- Kruskal Wallis testi sonuçlarına göre toplam üstsöylem belirleyicileri kullanımı, tüm gruplarda anlamlı bir şekilde farklılaşmaktadır $\left(x^{2}=15,262, p<0,05\right)$. Bu sonuçtan yola çıkılarak Mann Whitney $U$ testi ile denetlenen ikili grup karşılaştırmalarında ise, Türkçe Almanca iki dilli 4. sınıf Türkçe öğretmeni adaylarının toplam üstsöylem belirleyici kullanımlarının (Sıra Ort=58,68) Türkçe Almanca iki dilli 1. sınıf Türkçe öğretmeni adaylarından (Sıra Ort=41,23) anlamlı derecede daha fazla olduğu sonucuna ulaşılmıştır $(p<0,05)$. Türkçe tek dilli 1 . sınıf ve Türkçe tek dilli 4 . sınıf gruplarının Mann Whitney $U$ ikili toplam üstsöylem belirleyicileri karşılaştırma sonuçlarında anlamlı bir farklılığa ulaşılmamıştır $(p>0,05)$. Bu sonuca göre bu iki grupta toplam üstsöylem belirleyici kullanımının eş değer düzeyde olduğu görülmektedir. Türkçe Almanca iki dilli 1. sınıf ve Türkçe tek dilli 1. sınıf gruplarının toplam üstsöylem belirleyicileri Mann Whitney U ikili karşılaştırma sonuçları, Türkçe tek dilli 1. sınıf Türkçe öğretmeni adaylarının (Sıra Ort=65,41) toplam üstsöylem belirleyicilerini Türkçe Almanca iki dilli 1. sınıf Türkçe öğretmeni adaylarından (Sıra Ort $=44,37)$ anlamlı derecede daha fazla kullandığı sonucuna ulaşılmıştır $(p<0,05)$. Türkçe Almanca iki dilli 4. sınıf ve Türkçe tek dilli 4. sınıf Türkçe öğretmeni adaylarının Mann Whitney $U$ ikili toplam üstsöylem belirleyicileri karşılaştırma sonuçlarında anlamlı bir farklılığa ulaşılmamıştır $(p>0,05)$. Bu sonuca göre bu iki grupta toplam üstsöylem belirleyici kullanımının eş değer düzeyde olduğu görülmektedir.

- Kruskal Wallis testi sonuçlarına göre metinsel üstsöylem belirleyicileri kullanımının, tüm gruplarda anlamlı bir şekilde farklılaştığı görülmüştür $\left(x^{2}=16,661, p<0,05\right)$. Bu sonuçtan yola çıkılarak Mann Whitney $U$ testi ile denetlenen ikili karşılaştırmalarda ise, Türkçe Almanca iki dilli 4. sınıf Türkçe öğretmeni adaylarının metinsel üstsöylem belirleyici kullanımlarının (Sıra Ort=60,06) Türkçe Almanca iki dilli 1. sınıf Türkçe öğretmeni adaylarından (Sıra Ort=40,24) anlamlı derecede daha fazla olduğu sonucuna ulaşıımıştır $(p<0,05)$. Türkçe tek dilli 1 . sınıf ve Türkçe tek dilli 4 . sınıf gruplarının Mann Whitney $U$ ikili metinsel üstsöylem belirleyicileri karşılaştırma sonuçlarında anlamlı bir farklılığa ulaşılmamıştır $(p>0,05)$. Bu sonuca göre bu iki grupta metinsel üstsöylem belirleyici kullanımının eş değer düzeyde olduğu görülmektedir. Türkçe Almanca iki dilli 1. sınıf ve Türkçe tek dilli 1. sınıf gruplarının metinsel üstsöylem belirleyicileri Mann Whitney U ikili karşılaştırma sonuçları, Türkçe tek dilli 1. sınıf Türkçe öğretmeni adaylarının $($ Sıra Ort=64,78) metinsel üstsöylem belirleyicilerini Türkçe Almanca iki dilli 1. sınıf Türkçe öğretmeni adaylarından (Sıra Ort=44,96) anlamlı derecede daha fazla kullandığı sonucuna ulaşılmıştır $(p<0,05)$. Türkçe Almanca iki dilli 4. sınıf ve Türkçe tek dilli 4. sınıf Türkçe öğretmeni adaylarının Mann Whitney $U$ ikili metinsel üstsöylem belirleyicileri karşılaştırma sonuçlarında anlamlı bir farklılığa ulaşılmamıştır $(p>0,05)$. Bu sonuca göre bu iki grupta metinsel üstsöylem belirleyici kullanımının eş değer düzeyde olduğu görülmektedir.

- Kruskal Wallis testi sonuçlarına göre kişilerarası üstsöylem belirleyicileri kullanımında, gruplar arasında anlamlı bir farka ulaşılmamıştır ( $x 2=2,848, p<0,05)$. Bu 
nedenle kişilerarası üstsöylem belirleyicileri kullanımının dört grupta da benzer sıklıkta olduğu görülmektedir. Grupların kişilerarası üstsöylem belirleyicileri kullanımının eş değer düzeyde olması sonucunda Mann Whitney $U$ testi ile ikili karşılaştırmalar yapılmamıştır.

- Türkçe Almanca iki dilli 1. sınıf ve Türkçe Almanca iki dilli 4. sınıf Türkçe öğretmeni adaylarının üstsöylem belirleyicileri kullanımlarına bakıldığında, Kruskall Wallis ve Mann Whitney U testleri sonuçlarına göre hem metinsel (1. Sınıf Sıra Ort:40,24 - 4. Sınıf Sıra Ort:60,06) hem kişilerarası (1. Sınıf Sıra Ort:91,69 - 4. Sınıf Sıra Ort:97,68) hem de toplam (1. Sınıf Sıra Ort:41,23 - 4. Sınıf Sıra Ort:58,68) üstsöylem belirleyicilerini 4. sınıf Türkçe Almanca iki dilli Türkçe öğretmeni adaylarının anlamlı bir şekilde daha çok kullandığı görülmektedir. Bunun sonucunda, Duisburg Essen Üniversitesi Türkistik bölümündeki eğitim öğretim uygulamalarının üstsöylem belirleyicileri kullanımını sınıf düzeyine göre olumlu etkilediği görülmektedir.

- Türkçe tek dilli 1 . sınıf ve Türkçe tek dilli 4. sınıf Türkçe öğretmeni adaylarının üstsöylem belirleyicileri kullanımlarına bakıldığında, Kruskall Wallis ve Mann Whitney $U$ testleri sonuçlarına göre hem metinsel (1. Sınıf Sıra Ort:55,28 - 4. Sınıf Sıra Ort:49,12) hem kişilerarası (1. Sınıf Sıra Ort:109,27 - 4. Sınıf Sıra Ort:103,17) hem de toplam (1. Sınıf Sıra Ort:55,45 - 4. Sınıf Sıra Ort:49,55) üstsöylem belirleyicilerini 1. sınıf Türkçe tek dilli Türkçe öğretmeni adaylarının anlamlı bir şekilde daha çok kullandığı görülmektedir. Bunun sonucunda, Bolu Abant İzzet Baysal Üniversitesi Türkçe öğretmenliği lisans programındaki eğitim öğretim uygulamalarının üstsöylem belirleyicileri kullanımınında sınıf düzeyine göre olumlu bir etki söz konusu olmadığı görülmektedir.

- Öğretmen adaylarının sözcük kullanımına bakıldığında, tek dilli öğretmen adaylarının yazılı metinlerinde iki dilli öğretmen adaylarından daha fazla sözcük kullandığı görülmektedir. Üretilen metinlerdeki sözcük kullanımında, Türkçe tek dilli 4. sınıf Türkçe öğretmeni adayları ilk sırada yer almaktadır. Sonrasında sırasıyla Türkçe tek dilli 1. sınıf, Türkçe Almanca iki dilli 4. sınıf ve Türkçe Almanca iki dilli 1. sınıf Türkçe öğretmeni adayları gelmektedir. Ana dillerinde metin üretmeleri ve dili edinmeleri göz önüne alındığında, tek dilli Türkçe öğretmeni adaylarının sözcük kullanımlarının iki dilli Türkçe öğretmeni adaylarından daha yüksek olması doğaldır. Bununla beraber tek dilli ve iki dilli 4. sınıf Türkçe öğretmeni adayları, tek dilli ve iki dilli 1. sınıf Türkçe öğretmeni adaylarından daha fazla sözcük kullanmıştır. Bu durum, eğitim düzeyleri sonucu oluşan öğrenme yaşantıları ile açıklanabilir. Araştırmadan elde edilen bulgular aracılığıyla ulaşılan sonuçların yazılı anlatım ile metindilbilim derslerinin yapılandırılmasına katkıda bulunacağı düşünülmektedir. Sonuçlardan hareketle üstsöylem belirleyicileri alanında yapılacak olan sonraki çalışmalarda farklı metin türlerinde, farklı temel becerilere ilişkin farklı örneklem gruplarıyla incelemeler yapılabilir. İki dilli çalışma gruplarıyla ile yürütülecek olan çalışmalarda ise sahip olunan iki dilde de metin üretimleri gerçekleştirilebilir. Bununla beraber üstsöylem belirleyicileri kullanımları incelenirken ön test ile katılımcıların bilgi ve becerileri ölçüldükten sonra üstsöylem belirleyicileri dersleri verilip son test ile katılımcıların gelişim düzeyleri incelenebilir. Katılımcıların üstsöylem belirleyici kullanımları ile çeşitli değişkenler (cinsiyet, sınıf düzeyi, okuma alışkanlığı, sosyo-ekonomik düzey, öğretim programında yazılı anlatım ve/veya dilbilim dersleri bulunma vb.) arasındaki ilişkiler de incelenebilir.

\section{Araştırma ve Yayın Etiği}

Bu çalışmada "Yükseköğretim Kurumları Bilimsel Araştırma ve Yayın Etiği Yönergesi" kapsamında uyulması belirtilen tüm kurallara uyulmuştur. Yönergenin ikinci bölümü olan "Bilimsel Araştırma ve Yayın Etiğine Aykırı Eylemler" başlığı altında belirtilen eylemlerden hiçbiri gerçekleştirilmemiştir. 


\section{Etik Kurul İni}

Kurul adı = Bolu Abant İzzet Baysal Üniversitesi Sosyal Bilimlerde İnsan Araştırmaları Etik Kurulu Karar tarihi $=21.01 .2020$

Belge sayı numarası $=2020 / 04$

\section{Yazarların Katkı Oranı}

Makalenin hazırlanmasında 1. yazar \%60, 2. yazar \%40 oranında katkı sağlamıştır.

\section{Çıkar Çatışması}

Bu araştırmada çıkar çatışması teşkil edebilecek herhangi bir durum söz konusu değildir.

\section{Kaynaklar}

Adel, A. (2013). Metadiscourse. The encyclopedia of applied linguistics, 1-7.

Adel, A. (2018). Variation in metadiscursive "you" across genres: from research articles to teacher feedback. Educational Sciences Theory and Practice, 18, 777-796.

Aksan, D. (2015). Her yönüyle dil ana çizgileriyle dilbilim. Ankara: Türk Dil Kurumu Yayıncılık.

Baker, C. (2001). Foundations of bilingual education and bilingualism. UK: Multilingual Matters.

Bilgen, Ö. ve Doğan, N. (2017). Puanlayıcılar arası güvenirlik belirleme tekniklerinin karşılaştııılması. Eğitimde ve Psikolojide Ölçme ve Değerlendirme Dergisi, 8, 63-78.

Büyüköztürk, Ş., Çakmak, E., Akgün, Ö., Karadeniz, Ş. ve Demirel, F. (2013). Sosyal bilimler için veri analizi el kitabı. Ankara: Pegem Yayıncılık.

Büyüköztürk, Ş. (2015). Sosyal bilimler için veri analizi el kitabı. Ankara: Pegem Yayıncılık.

Crismore, A., Markanen, R., \& Steffensen, M. (1993). Metadiscourse in persuasive writing: a study of texts written by American and Finnish university students. Written Communication, 10, 39-71.

Cummins, J. (2001). Bilingual children's mother tongue. Sprogforum, 19, 15-20.

Çapar, M. (2014). Araştırma makalelerinde etkileşimsel üstsöylem öğeleri (Yayınlanmamış doktora tezi). Anadolu Üniversitesi Eğitim Bilimleri Enstitüsü, Eskişehir.

Dahl, T. (2004). Textual metadiscourse in research articles: a marker of national culture of academic discipline. Journal of Pragmatics, 36, 1807-1825.

Dağ Tarcan, Ö. (2019). Türkçe bilimsel metinlerde etkileşimli üstsöylem belirleyicileri (Yayınlanmamış doktora tezi). Ankara Üniversitesi Sosyal Bilimler Enstitüsü, Ankara.

Doyuran, Z. (2009). Conciliation of knowledge through hedging in turkish scientific articles. Hacettepe Üniversitesi Edebiyat Fakültesi Dergisi, 1, 85-99.

Esmer. E. (2009). Söylem belirleyicisi ki'nin işlevlerinin ezgi ile desteklenmesi. Dil ve Edebiyat Dergisi, 1, 1-16.

Esmer, E. (2018). Türkçeyi yabancı dil olarak öğrenen öğrenciler tarafından üretilen ikna metinlerinde üstsöylem belirleyicilerinin kullanımı. Dil Eğitimi ve Araştırmaları Dergisi, 3, 216-228.

Fidan, Ö. (2002). Türkçe bilimsel metinlerde üstsöylem belirleyicileri (Yayınlanmamış yüksek lisans tezi). Ankara Üniversitesi Sosyal Bilimler Enstitüsü, Ankara.

Fuertes-Olivera, P., Velasco-Sacristan, M., Arribas-Bano, A., \& Samaniego-Fernandez, E. (2001). Persuasion and advertising English: metadiscourse in slogans and headlines. Journal of Pragmatic, 33, 1291-1307.

Gillaerts, P., \& Van de Velde, F., (2010). Interactional metadiscourse in research article abstracts. Journal of English for Academic Purpos, 9, 128-139.

Günay, D. (2015). íki ya da çok dillilik ve Avrupa toplumu. Turkophone, 2, 68-72.

Günay, D. (2017). Metin bilgisi. İstanbul: Papatya Yayıncılık.

Güneş, F. (2016). Türkçe öğretimi: yaklaşımlar ve modeller. Ankara: Pegem Yayıncılık.

Güzel, A. (2014). iki dilli Türk çocuklarına Türkçe öğretimi: Almanya örneği. Ankara: Akçağ Yayıncılık.

Huber, E. (2013). Dilbilime giriş. İstanbul: Yabancı Dil Yayınları.

Hyland, K. (1996). Writing without conviction hedging in science research articles. Applied Linguistics, $17,433-454$. 
Türkçe Almanca İki Dilli ve Türkçe Tek Dilli Türkçe Öğretmeni Adaylarının Yazılı Metinlerinde Üstsöylem Belirleyicileri

Hyland, K. (1998). Persuasion and context: the pragmatics of academic metadiscourse. Journal of Pragmatics, 30, 437-455.

Hyland, K. (2000). Disciplinary discourses: social interactions in academic writing. ABD: University of Michigan Press.

Hyland, K. (2005). Metadiscourse: exploring interaction in writing. London: Continuum.

Kan, M. O. (2016). The use of interactional metadiscourse: a comparison of articles on Turkish education and literature. Kuram ve Uygulamada Ĕgitim Bilimleri Dergisi, 16(5), 1639-1648.

Karaağaç, G. (2011). Bireysel iki dillilik ve toplumsal iki dillilik. Türk Dili Dergisi, 717, 222-228.

Karakuş, N. (2020). Ingilizce öğretmenlerinin ikinci dilde akademik yazımda kişisel ve kişisel olmayan üstsöylem belirleyicilerine ilişkin farkındalık ve tutumları (Yayınlanmamış yüksek lisans tezi). Orta Doğu Teknik Üniversitesi Sosyal Bilimler Enstitüsü, Ankara.

Karasar, N. (2012). Bilimsel araştırma yöntemleri. Ankara: Nobel Yayıncılık.

Kaya, F. (2019). Üstsöylem belirleyicilerinin doğrudan öğretiminin öğrencilerin yazma yeterliliklerine etkisi ve ögrrencilerin süreç hakkındaki görüşleri (Yayınlanmamış doktora tezi). Çukurova Üniversitesi Sosyal Bilimler Enstitüsü, Adana.

Kıran Z. ve Kıran A. (2018). Dilbilime Giriş. Seçkin Yayıncılık.

Kirişçi, D. I. (2020). Türk ve Ingiliz araştırmacılar tarafından yazılan makalelerin özetlerindeki üstsöylem belirleyicileri (Yayınlanmamış yüksek lisans tezi). Bahçeşehir Üniversitesi Eğitim Bilimleri Enstitüsü, İstanbul.

Kopple, W. J. V. (1985). Some exploratory discourse on metadiscourse. College Composition and Communication, 36(1), 82-93.

Köroğlu, Z. (2017). Ana dili ingilizce olan ve olmayanların yüksek lisans ve doktora tezlerindeki üstsöylem etkileşim: bağlaçların durumu (Yayınlanmamış doktora tezi). Çukurova Üniversitesi Sosyal Bilimler Enstitüsü, Adana.

Mackey, W. F. (1962). The description of bilingualism. Canadian Journal of Linguistics Revue Canadienne de Linguistique, 7, 51-85.

Molali, N. (2005), Romanya Türk toplulukları örneğinde iki dillilik (Yayınlanmamış doktora tezi). Gazi Üniversitesi Sosyal Bilimler Enstitüsü, Ankara.

Önel, M. A. (2020). Türkçe eğitimi alanında yapılmış yüksek lisans tezlerinde kişsilerarası üstsöylem belirleyicilerinin betimlenmesi (Yayınlanmamış yüksek lisans tezi). Mersin Üniversitesi Eğitim Bilimleri Enstitüsü, Mersin.

Özbek, N. (1998). Türkçede söylem belirleyicileri. Dilbilim Araştırmaları Dergisi, 9, 37-47.

Rolffs, S. (2009). Yine iki dillilik üzerine. Die Gaste, 5, 7-8.

Schiffrin, D. (1980). Metatalk: organisational and evaluative brackets in discourse. Sociological Inquiry: Language and Social Interaction, 50, 199-236.

Şen, E. (2019). Bilimsel makale özetlerinde üstsöylem belirleyicilerinin incelenmesi (Yayınlanmamış doktora tezi). Dokuz Eylül Üniversitesi Sosyal Bilimler Enstitüsü, İzmir.

Tokdemir, A. (1997). Dil edinimi ve yabancı dil. Ankara: Sam Yayınları.

Ulu, B. (2020). Yabancı dil olarak Ingilizce öğrenenlerin yazılarındaki üstsöylem belirleyici kullanımının dinamik değerlendirilmesi (Yayınlanmamış yüksek lisans tezi). Kocaeli Üniversitesi Sosyal Bilimler Enstitüsü, Kocaeli.

Uluçam Wegmann, A. I. (2007). İki dilli öğrencilerin yazılı metin üretimindeki sorunları. Dil Dergisi, 135, 8-43.

Uzun, L. (2002). Dilbilim alanında Türkçe yazılan araştırma yazılarında metin dünyasına ilişkin düzenlemeler içinde L. Uzun \& E. Huber (Ed.), Türkçede bilgi yapısı ve bilimsel metinler (ss. 202224). Essen: Die Blaue Eule.

Ünsal, Ö. (2008). Fen bilimleri ve sosyal bilimler alanlarındaki akademik makalelerde kullanılan üstsöylem belirleyicilerinin karşılaştırmalı çalışması (Yayınlanmamış yüksek lisans tezi). Çukurova Üniversitesi Sosyal Bilimler Enstitüsü, Adana.

Vardar, B. (1988). Açıklamalı dilbilim terimleri sözlüğü. İstanbul: ABC Yayınevi.

Yağmur, K. (2007). íki dilli çocukların dil becerilerinin ölçümü ve eşik kuramı. Dil Dergisi, 135, 60-76.

Yıldııı, A. Şimşek, H. (2016). Sosyal bilimlerde nitel araştırma yöntemleri. Ankara: Seçkin Yayıncılık. 
Yuvayapan, F. (2018). Etkileşimsel üstsöylem ögelerinin yazar duruşunu sağlamadaki pragmatic rolü: doktora tezlerinden oluşan diller arası bir çalışma (Yayınlanmamış doktora tezi). Erciyes Üniversitesi, Kayseri.

Zeyrek, D. (2002). Psikoloji makalelerinde üstsöylem belirleyicileri içinde L. Uzun \& E. Huber (Ed.), Türkçede bilgi yapısı ve bilimsel metinler (ss. 224-242). Essen: Die Blaue Eule.

\section{Extended Abstract}

\section{Introduction}

The descendants of Turks who transitioned from temporary worker status to settled life in Germany grew up nurtured by both German and Turkish culture. This led to the emergence of bilingualism in Turkish And German. Uluçam Wegmann (2007) states that the learning environment in which bilingual individuals living abroad and individuals living in a region dominated by their mother tongue in Turkey differ and this difference is reflected in the language use of individuals. Individuals are expected to express themselves competently in both languages. When transferring the language to writing, it becomes important to know the level at which they produce text. Metadiscourse markers are used to ensure that the generated text is understood by the reader. In this research, the metadiscourse markers used in the production of written texts by Turkish German bilingual Turkish Language teacher candidates and Turkish monolingual Turkish Language teacher candidates were identified and categorized according to Hyland's taxonomy of metadiscourse. It is thought that the research will contribute to the structuring of Written Expression and Textlinguistics courses.

\section{Method}

The method of the study was survey and correlational research design. The study group was selected through purposeful sampling. The group consists of 56 freshman and 40 senior Turkish Language teacher candidates studying in the Turkistic Department of Duisburg Essen University and 52 freshman and 52 senior teacher candidates studying in the Turkish Language Teaching undergraduate program of Bolu Abant İzzet Baysal University. Participant Recognition Form and Written Expression Form were used as data collection tools. Turkish teacher candidates were asked to produce texts by selecting subjects from the Written Expression Form. The texts were analysed individually by two experts according to Hyland's classification of the metadiscourse markers. The frequency and distribution data of the metadiscourse markers were evaluated using the SPSS package program.

\section{Result and Discussion}

When looking at the use of metadiscourse markers of all groups, the group that uses the most are Turkish monolingual freshman Turkish Language teacher candidates. Turkish- German bilingual freshman Turkish Language teacher candidates come in the last place. This can be explained by the fact that monolingual teacher candidates care more about the reader of the text in the process of text production. In all groups, textual metadiscoure markers were used more than interpersonal metadiscourse markers. This result supports the study findings of Hyland (1998), Long (2002), Sapling (2002), Esmer (2018) and Dag Tarcan (2019) that conclude textual metadiscourse markers are used more than interpersonal metadiscourse markers. When we look at the word usage of Turkish teacher candidates, it is seen that monolingual teacher candidates use more words in their written texts than bilingual teacher candidates. This can be explained by the learning experiences that occur as a result of their educational level. 